University of Nebraska - Lincoln

DigitalCommons@University of Nebraska - Lincoln

Faculty Publications - Modern Languages and Modern Languages and Literatures, Department Literatures

\title{
What Women Know: The Power of Savoir in Marguerite de Navarre's Heptaméron
}

Nora Martin Peterson

University of Nebraska-Lincoln, npeterson10@unl.edu

Follow this and additional works at: https://digitalcommons.unl.edu/modlangfacpub

Part of the European Languages and Societies Commons, French and Francophone Language and Literature Commons, Modern Languages Commons, and the Renaissance Studies Commons

Peterson, Nora Martin, "What Women Know: The Power of Savoir in Marguerite de Navarre's Heptaméron" (2017). Faculty Publications - Modern Languages and Literatures. 33.

https://digitalcommons.unl.edu/modlangfacpub/33

This Article is brought to you for free and open access by the Modern Languages and Literatures, Department of at DigitalCommons@University of Nebraska - Lincoln. It has been accepted for inclusion in Faculty Publications Modern Languages and Literatures by an authorized administrator of DigitalCommons@University of Nebraska Lincoln. 


\section{What Women Know: The Power of Savoir in Marguerite de Navarre's Heptaméron}

\section{Nora Martin Peterson}

A U TEMPS DU ROY FRANÇOIS, premier de ce nom, y avoit une dame [...] qui sçavoit bien faire ung bon compte," begins novella 62 of the Heptaméron (451), and although the story goes on to revolve around a woman who does not know how to tell her tale properly, readers are reminded that Marguerite de Navarre, who is implied to be this noble lady, knows how to tell a good story. ${ }^{1}$ Both savoir and connaître appear regularly throughout the Heptaméron. According to Le Grand Robert, both verbs take the sense of avoir présent à l'esprit starting in the tenth century. Around the same time, savoir also means "to know how to do something," and in the eleventh century, connaître means "to experience something," to know how to do something or to know a person. Around the end of the same century, connaître also takes on sexual connotations. Thus, by the sixteenth century, a wide range of definitions would have been in play simultaneously, and Marguerite de Navarre takes full advantage of the spectrum of meanings in the Heptaméron. In a text that purports to be filled with stories that its tellers (the five men and five women of the frame, who together make up the devisants) know to be true, knowledge - wielding it, representing it, and using it to make a rhetorical point - commands a central role in the frame. As a writer who was deeply invested in educating women and in advocating for a strong female presence in early modern society, Marguerite de Navarre uses her Heptaméron as a site from which she can promote and experiment with different kinds of female knowledge.

In this article I will argue that savoir - either the word itself or a demonstration of female-directed knowledge - appears at central moments in the Heptaméron. $^{2}$ Knowledge - as can be seen in the frame narrative - can be a way for men and women to debate the relationship between the sexes. In the novellas, knowledge is a tool that can put women in charge of a narrative normally driven by men. It can heal the injustices of male-dominated religious corruption. But, as with almost any theme in the Heptaméron, knowledge is not an unequivocally positive tool for women. Marguerite also includes novellas in which female knowledge has ambiguous, or even disastrous, consequences for women. These stories seem to warn women that knowledge is not always a trustworthy harbinger of success. It can also lead to the loss of

(C) L'Esprit Créateur, Vol. 57, No. 3 (2017), pp. 21-32 
reputation or honor. Knowledge, then, is a double-edged sword that can be at odds with virtue, and that women must learn to wield wisely. But, I will ultimately suggest, Marguerite is certainly not implying that women shouldn't know things. Nor does she shy away from portraying women who use knowledge badly. Rather, the tension between different kinds of women and their (ab)uses of knowledge reveals a text grounded in seemingly unresolvable contradictions. Indeed, the instability in the Heptaméron that can be so frustrating also reflects its openness to multiplicity; any sign of equilibrium or unanimity should be approached with caution. ${ }^{3}$ While Gérard Défaux writes that the "beau souci d'équité [qui est] la véritable marque de fabrique du texte," I will argue that the sculpting of the frame to appear completely equitable, along with the carefully designed balance between the spiritual and worldly, allows the dialogism in and between these spheres to play out internally (Défaux 133). When women use savoir in the Heptaméron, or when they demonstrate that they know something, it fuels a conversation-not always an unambiguous one - about women's roles in communities of knowledge.

What women know, and how the text reflects the acquisition, possession or loss of knowledge, creates a network of female-driven knowledge that underscores the author's interest in promoting a strong female voice, reminding readers that ultimately it is Marguerite herself who is managing the conversation. In recent years, scholars have questioned whether the Heptaméron is a participant in the Querelle des femmes tradition due to its departure from many of its hallmark techniques. Notably, as Carol Thysell points out in The Pleasure of Discernment, it is not polemical, there is no catalog of famous women, and it favors personal experience over the erudition of the past. ${ }^{5}$ Nancy Frelick has also called into question the reliability of Marguerite's proto-feminist stance; she reminds readers that it is unclear whether Marguerite is "eager to expose the condition of women" or more willing to grant women the subordinate role, since the text relentlessly oscillates between both. ${ }^{6}$ Indeed, this instability and openness is part of what drives the conversation; it is, I believe (and I am hardly the first to argue so), part of what makes the Heptaméron so vibrant and so representative of sixteenth-century thought (Frelick 25). Indeed, it is true, as Cathleen Bauschatz has argued, that the Heptaméron does not prescribe one way for women to read, listen or use words. ${ }^{7}$ For example, Bauschatz suggests that although the Heptaméron implies a female readership with the rhetorical "voylà, mes dames" at the end of almost every novella (105), it actually reverses this message: "while [the phrase] seems to offer women listeners a secure guide to behavior, the reactions of the women to the phrase show that these precepts are suspect, and must often be rejected" (113). Women speakers, 
listeners, and devisantes must employ a certain sçavoir regarding the words of this text. They must know when to take words at face value, when to reverse them, and when to understand them within a broader context. And, as Hope Glidden writes, "fiction writing [...] is a dissimulation —of sources, of realia, of the contradictions that move its plots. The female author, as woman, is thus twice a dissimulator, as a woman, and functionally as a male in her appropriation of language." 8 By strategically using savoir as an educational tool for her readers, Marguerite's voice is very much there, despite her careful work to keep her presence an explicitly neutral one.

Thus, though it is true that the Heptaméron does depart from certain traditional characteristics, the Querelle des femmes was a fluid conversation that developed over many centuries. Marguerite de Navarre's text reinvents the techniques of the Querelle in ways that ultimately work in favor of women by breaking up the very binaries according to which women would be seen as superior or inferior. Marguerite does more than reverse the injustices against women; to do so would be, as Frelick has pointed out, to create a reiteration of the same problem (23). Instead, the lack of resolution creates a new system "wherein the binary categories [...] no longer apply" (23). Indeed, what this text grants women is the possibility to use the inherent ambiguity of words, and of the many things that female knowledge has come to mean, to their advantage. ${ }^{9}$ By going out of her way to make the novellas more balanced, and by focusing on debate, even (or especially) when no resolution can be reached, and by the sheer fact that she is a woman writing this text, Marguerite subverts the male argument that female knowledge is harmful and/or insignificant, presenting that knowledge instead as a way to gain "power in spoken and written language" (Bauschatz 116).

\section{Framing knowledge}

"Au jeu nous sommes tous esgaulx" (12), proclaims Hircan, thus apparently laying the groundwork for the discussions between the ten devisants that will follow each tale. Indeed, this quote, along with the balance between Scripture and storytelling that is to structure each of the days in the Heptaméron, is commonly cited as one of the leitmotifs of the text. But Hircan's statement and the apparent balance between religious and secular deserve a closer reading that accounts for the appearance of the word savoir and Marguerite's interest in promoting a strong female voice.

In the prologue, Oisille takes on the spiritual direction of the devisants. ${ }^{10}$ Though they do benefit from the daily routine of the abbey at which they are lodged, it is her expertise - which is notably not male and not that of a 


\section{L'ESPRIT CRÉATEUR}

monk - that guides the devisants towards an increasingly satisfactory religious experience. ${ }^{11}$ She recounts her own personal practice, developed over many years, which consists of "la lecture des sainctes lectres [...] incontinant que je suis levée, je prans la Saincte Escripture et la liz" (9). She suggests that the devisants pass their days in spiritual reflection and prayer. Hircan's response, a proposition of sexual pleasure (10), pits the spiritual and carnal extremes against each other in a juxtaposition of sexuality and spirituality that will coexist - at times uneasily - in the Heptaméron. Hircan is in turn tempered by his wife Parlamente's diplomatic compromise (prayer in the morning, followed by an afternoon of storytelling until vespers), which the devisants happily accept (10-12). I wish to highlight the exchange between Hircan and Parlamente here:

Hircan dist à toutes les dames: "Puisque ma femme a si bien entendu la glose de mon propoz et que ung passetemps particullier ne luy plaist pas, je croy qu'elle sçaura myeulx que nul autre dire celluy où chacun prandra plaisir [...]"A quoy toute la compagnye s'accorda. Parlamente, voiant que le sort du jeu estoit tumbé sur elle, leur dist ainsy: "Sy je me sentoys aussy suffisante que les Anciens, qui ont trouvé les artz et inventions nouvelles, je inventerois quelque jeu ou passetemps pour satisfaire à la charge que me donnez. Mais, congnoissant mon sçavoir et ma puissance, qui à peine peult rememorer les choses bien faictes, je me tiendrois bien heureuse d'en suivre de près ceulx qui ont desja satisfaict à vostre demande." (10-11, emphasis mine)

Hircan's words to his wife hint at her understanding of his sexual proposal ("elle sçaura myeulx"), thus his deferral is at least in part ironic. But Parlamente makes the most of her prise de parole and reclaims knowledge from the realm of the flesh. Leaning on what might be read as (false) modesty, Parlamente rhetorically underscores the extent to which she is in control of the narrative. She takes Hircan's quip and, using both verbs of knowledge, insists that she will rely on what she knows, and she goes on to propose the structure of splitting their time between spiritual and secular pastimes. Hers is a knowledge that gives direction to the entire text, reconciles the coexisting threads of religion and pleasure, and empowers the women of the group to participate in the creation of stories.

Between them, Oisille and Parlamente take control of the Heptaméron's frame. Oisille establishes herself as spiritual guide, and Parlamente converts her knowledge into a plan of action. Turning once again to the proclamation of equality at the end of the prologue, readers might wonder why, when he has deferred any and all such powers to his wife, Hircan gets to be the mouthpiece of equality. Gisèle Mathieu-Castellani suggests that "Marguerite est à la fois Parlamente et Hircan, Oisille et Simontault, Longarine et Saffredent: 
partagée, non point entre réalisme cynique et idéalisme naïf, mais entre les exigences de l'honnêtetée [...] et les tentations du plaisir."12 By giving textual equality to men and women during the game, and by splitting her voice until it is "si discrète qu'elle semble parfois se réduire à celle d'une auditrice, enregistrant contes et débats sans vouloir les orienter" (203), Marguerite's women have free reign to explore their own voices. By establishing Oisille and Parlamente as the ones who know how to run the project, then allowing a man to 'generously' suggest that even women are free to speak, Marguerite and the women of the Heptaméron accept the subtly misogynistic terms of equality offered by Hircan only to turn them upside down and open them up to the scrutiny of women who know the power of language. ${ }^{13}$ At the end of the discussion to novella 46, Oisille insists that the judgment of women should fall to women themselves: "La correction des hommes appartient aux hommes et des femmes aux femmes; car les femmes à corriger les hommes seroient aussi piteuses que les hommes à corriger les femmes seroient cruels" (375). Defaulting to the subservient position (again, an echo of the Querelle des femmes) that women would not be fit to judge men, she turns the logic around to make women the bearers of judgment upon their own sex. As such, the Heptaméron establishes a world in which women play an active role in shaping the language of their own stories.

\section{Marguerite on the margins}

Marguerite's fictional appearances in her own text underscore her interest in promoting what women know and, more importantly, what they can do with the knowledge they acquire. References to the author also remind readers who is in charge; often, her responses highlight the power of women to heal or to correct misogynistic injustices where institutions, such as religion, cannot. The strategic use of the verbs savoir and connaitre drives the narrative of various novellas and allows the author to demonstrate her ability to navigate the nuances behind different kinds of knowledge.

In novella 25, Marguerite, alluded to as the sister of a thinly veiled François Ir ${ }^{\text {er }}$ learns that her brother is using a nearby monastery as a shortcut on his way to and from his lover's house. When a monk lauds François's alleged piety, her curiosity is piqued: "La seur, qui eut envye de sçavoir quelle congnoissance ce beau pere avoit de la bonté de son frere, l'interrogua si fort que, en luy baillant ce secret soubz la foe de confession, luy dist" (253, emphasis mine). He goes on to reveal François's frequent appearances in the house of prayer. Marguerite's will to knowledge leads to a confession - she and the monk trade roles in a move that puts her in charge of the narrative. 
Because she knows her brother well, Marguerite is immediately skeptical: "[elle] ne sceut que croire; car, nonobstant que son frere feust bien mondain, sy sçavoit elle qu'il avoit la conscience tresbonne et la foy et l'amour à Dieu bien grande, mais de chercher supersticions ne ceremonyes autres que ung bon chrestien doit faire, ne l'en eust jamais soupsonné" (253, emphasis mine). What she knows (learns) from the monk stands in tension with what she knows about her brother's religious life. As a result of this tension, she confronts her brother to learn the truth: "elle s'en vint à luy et luy compta la bonne oppinion que les religieux avoient de luy: dont il ne se peut garder de rire, avecques ung visaige tel qu'elle, qui le congnoissoit comme son propre cueur, congneut qu'il avoit quelque chose caché soubz sa devotion" (253, emphasis mine). What Marguerite has learned from the monk provokes a physiological reaction from François. It is enough to show his sister that there is more to the story, which he goes on to tell. Though this is a lighthearted example of Marguerite's knowledge, it nonetheless reveals a woman in a powerful position: she navigates the confessions of a monk and a king and can parse the differences in each of their confessions. Knowledge is a work in progress, but it is Marguerite who wields it; she uses it to unravel the narrative and to reveal the amusing (but not so moral) way that François uses religion as an excuse to perpetuate his tryst with his lover. By finding the truth, she comes out as the knowledgeable heroine of the story, whereas the monk and François both look comical by comparison. ${ }^{14}$ And by retelling the story, shrouding it in the many layers of storytelling that make up the Heptaméron's fabric, she suggests that women have the power to command a narrative that has been used only for increasingly corrupt and self-serving purposes by men.

In novellas where more is at stake for the women involved, Marguerite's presence and knowledge play an even more poignant role. In both novellas 22 and 72, women are duped into disgrace by corrupt members of the Church. ${ }^{15}$ In the former, Marie Herouet, who refuses to sleep with a lusty clergyman, is sentenced to a life of isolation for her supposedly lewd behavior. Marguerite is called upon to investigate, and, when she goes to question the prior for his decision to treat Marie in this way, "il confesseroit que seur Marie Herouet estoit une perle d'honneur et de virginité. La royne de Navarre, oyant cella, fut tant esmerveillée qu'elle ne sceut que luy respondre, mais le laissa là, et le pouvre homme, tout confuz, se retira en son monastere" (227, emphasis mine). The text's emphasis of Marguerite's speechlessness, described here in a common turn of phrase as not knowing how to respond, suggests that the withholding of knowledge can be a powerful rhetorical tool. Marguerite is usually eloquent and knowledgeable, and more than willing to pass judgment, espe- 
cially when women have been unfairly wronged, and so her silence is more telling than any words would have been. As a result, the prior feels the weight of her silence and is shamed into retiring. The same turn of phrase appears in the discussion of the novella. Nomerfide proclaims, "j'ay une si grant horreur, quant je veoy ung religieux, que seulement je ne m'y sçaurois confesser" (228). The ambiguity in this turn of phrase, which implies both not knowing how to make a proper confession and also not wanting to because of the corruption of the sacrament, echoes the fictional Marguerite's not knowing how to respond to the prior. Lack, or absence of knowledge, stands in for the larger sense of awareness (raised here by women) that something is not right.

In novella 72 , a young girl is seduced repeatedly by a prior, under repeated threat, until she falls pregnant. Mocked and ostracized by the women of her order and the wicked prior, she leaves. Though her original plan is to seek absolution from the pope, she is intercepted by a woman who turns out to be Marguerite herself. Wary of telling her story to just anyone, the girl insists that she will share her story only with the Queen of Navarre: "pardonnez moy, dist la religieuse, car jamais autre que elle ne sçaura mon secret" (507, emphasis mine). Taking the place of the pope, Marguerite herself hears the girl's confession, takes control of the narrative, and rights the wrongs in this novella. As the last novella in the Heptaméron (though not by design), readers are left with the message that women, and what they know, are powerful agents of healing, justice, and community. As Mary McKinley suggests, in both novellas 22 and 72 "the story ends with a woman of authority reestablishing order, helping the female victim to resume normal life in a community of women and having the wicked priest punished" (163). Marguerite's careful but intentional cameo appearances make readers aware of the metatextual knowledge that is guiding the entire text. Her fictional character also insists that knowledge is something quite natural for women to possess, to wield, and to use as an agent of positive change. In this sense, knowledge - as a verb, as an action, and even in its absence-very much underscores a reading of the Heptaméron as a text interested in exploring the power of words. However, it is also a text that shifts between text and metatext, and between truth and fiction. What of the equally problematic shifting between knowledge and ignorance? What of women whose knowledge leads them to bad behavior, or of those who suffer because of what they do not know?

\section{Ambiguous women and knowledge}

Novellas 26 and 43 have frequently been read as stories of virtuous and wanton women, respectively. These are the conclusions drawn by the 
devisants (though not unequivocally), and the two novellas can easily be read against one another. Hope Glidden, for example, emphasizes the troubling nature of both extremes - to repress one's feelings to the point of death, in the case of novella 26 , and to indulge in one's desires without reservation, with a particular emphasis on the androgynous representation of Jambicque in novella 43 as non-woman: "it is so unthinkable for a woman to display desire that when she does, she is often redescribed as a male" (30). To contrast the two stories, however, is to miss what they share: women who themselves are deeply conflicted. Both the Lady of Pampluna and Jambicque manifest characteristics that render them ambiguous, even androgynous, but not in a way that limits our interpretations of these characters. Quite to the contrary: what these women know heightens the hybridity of their stories and complexifies a straightforward reading. The Lady of Pampluna, who resists and dissimulates the advances of her honorary ward despite the reciprocity of her feelings, only to succumb to a melancholic fever - she seems to hold a double standard. After the Seigneur d'Avannes returns from his "pilgrimage" (actually a sexual escapade), she chastises him, "Monsieur, je ne sçay comme il va de vostre conscience, mais vostre corps n'a poinct amandé de ce pellerinaige" (260), though it is quite clear that she does, in fact, know with what kinds of activities his conscience has been occupied. Later, though the text states quite clearly that she is happy to hear his true feelings, she dissimulates her own: "Je sçay tresbien que je suis femme [...] et à l'heure, Monsieur, je sçay quel langaige il fault tenir, mais pensez que vous n'aymez pas tant vostre propre bien, personne ny honneur, que je l'ayme" (263). Invoking the "I know that I am a woman" defense that (as we have already seen) is cleverly ambiguous, the Lady of Pampluna shows what she knows selectively: she demonstrates awareness of her position, proper behavior, and a sense of modesty, but she does not reveal her true feelings. Her supposedly clever employment of savoir backfires on her in the end: it shows no regard for the sexual connotations of knowledge or for the tension between what she desires and how she acts. She confesses: "Monsieur, l'heure est venue qu'il fault que toute dissimulation cesse [...] mais saichés que le 'non' que si souvent je vous ay dict m'a tant faict de mal au prononcer qu'il est cause de ma mort, de laquelle je me contante" (266). The Lady of Pampluna shows insight into her predicament: she knows that her repeated refusals are the cause of her death, and she claims to be happy about her decision to refuse him nonetheless. At the same time, it is unclear how to reconcile her purported virtue with her hypocrisy (as sharply critiqued by Hircan in the discussion). The Lady knows her feelings, she is also aware of d'Avannes's, but she uses what she knows to maintain her virtue 
at all costs. ${ }^{16}$ True, readers are left with the portrait of an unrelentingly virtuous woman, but I believe that Marguerite acknowledges the ambiguity of this extreme: that virtue sometimes comes at a cost that, for some, might be too steep, leaving them looking like fools rather than heroes.

The devisants are quick to condemn Jambicque, the lady in novella 43 who pursues the object of her lust anonymously, and who maintains this tryst until her lover marks her cloak with chalk in order to determine her identity, as an example of unruly female desire. However, while the discussion centers on Jambicque's folly, the story itself raises questions about what it means to know someone - or oneself. I wish to focus only on Jambicque's use of the word savoir in one key passage. It is a savoir that separates her physical body from her identity. When she approaches the object of her desire in order to proposition him as her lover, she insists on anonymity, proclaiming, "J'aymerois myeulx mourir que vous sceussiez qui je suis" (361). Clearly, she has no problem with the man's knowing her sexually, but the savoir here constructs a wall around the non-physical part of her identity — her self, her name, her reputation. This view contrasts with that of Glidden, who writes that while Jambicque "saves face," she also loses it, by being redefined as a body having no identity apart from her sexual organs" (Glidden 31). But in fact, by separating the physical and non-physical parts of herself with the nuance of the word savoir, Jambicque does-or seeks to do-exactly this, to define herself as a lady who does have an identity apart from her sexual organs. To be sure, her behavior and lust may make her look more like a man than a woman, but as a woman, she recognizes what is at stake in her decision to pursue a purely sexual relationship, and she seeks to protect it by splitting her self into two parts, a reading corroborated by the use of the verb savoir here, which creates a contrast to the carnal knowledge of connaître (which, again, she expresses no opposition to pursuing). Paula Sommers writes that Jambicque is suffering from "strong feelings of guilt and unworthiness," but I would suggest that the situation is more complex. ${ }^{17}$ Realizing the scrutiny and judgment that women face at court, she takes necessary and proactive steps to remain anonymous. Of course, the lover's desire to know triumphs in the end, and he calls her out. Her denial of the whole affair pits his knowledge against her vow never to be found out, and while readers and devisants know the truth, Jambicque seems to get away with her reputation intact, a point that suggests that her attempt to compartmentalize different kinds of knowledge was indeed successful.

In novella 62 , on the other hand, it is made clear that the storyteller does lose her honor, not necessarily as the result of her actions, but as the result of her decision to tell her story for the amusement of others. Perhaps most impor- 
tant, it is not knowing how to tell the story properly, in front of an audience that explicitly knows the difference, that ruins her. The novella (told by Longarine) begins: "Au temps du roy François, premier de ce nom, y avoit une dame du sang royal, acompaignée d'honneur, de vertu, et de beaulté, et qui sçavoit bien faire ung bon compte" (451, emphasis mine). Notably, the woman described in these opening lines is not the woman who is about to tell her story. Rather, she is a versed storyteller, and one who is graced with many of the same virtues that writers in the tradition of the Querelle des femmes would celebrate. Indeed, the devisants (in particular, the devisantes) insist on these same qualities in several discussions, notably after novella 43, where Parlamente chastises Jambicque for lacking them: "l'honneur des femmes a autre fondement: c'est douceur, pascience et chasteté" (365). Mathieu-Castellani suggests that "si Parlamente est assez audacieuse pour contester les normes socio-culturelles de l'éthique masculine, elle exprime les opinions les plus traditionnelles pour définir l'honneur féminine" (198). Through a complex mise en abyme, the Heptaméron suggests that female knowledge must be combined with virtue. Novella 62's mise en abyme of storytellers and listeners is almost dizzying: author Marguerite, narrator Longarine, the good storyteller of royal blood (Marguerite herself?), the bad storyteller who gives herself away. As for listeners, there are the devisants, the readers, the same (good) storyteller, and the other ladies who are present. I believe that Marguerite intentionally creates multiple layers of readers and narrators in order to create a diverse community of listeners. Stories, and by extension texts, have an important role to play in the education of women. By linking virtue with storytelling, novella 62 underscores two of the Heptaméron's messages: first, that strong women know how to tell good stories, and second, that language, knowledge, and virtue carry the power to change lives - for better or worse. Women, in turn, must learn how to use what they know. When applied thoughtfully, knowledge can protect, heal, reconcile or triumph over injustice. However, knowledge is rarely so straightforward. The protagonist of novella 62 , who knows the truth of what has happened before she begins her story, cannot control the words that accidentally come out of her mouth. Purposely juxtaposed with the virtuous, honorable, and beautiful lady who can wield her words well, she represents what happens when knowledge gets out of hand, and she suffers the consequences.

Far from straightforwardly quantifying what women know (or do not know or should/not know), the Heptaméron creates a (literal) community of hybrid knowledge. At times, Marguerite "reproduces the sexual typologies of the querelle des femmes," apparently, in other moments, "only to subvert them.."18 
The author's experiments with women who know things or do not know things, and who either know what to do with their knowledge or do not, are complemented by the appearance of verbs of knowledge such as savoir and connaître throughout the text. Ultimately, even in cases where the woman employs knowledge badly, or does not know something that she should, what women know becomes textually embedded in an open conversation about gender. The Heptaméron's oscillation between viewpoints results in a text that "met en scène un conflit dont il ne peut assurer la solution par le simple jeu des opinions contraires" (Mathieu-Castellani 200). Could there be a better way to represent the Querelle des femmes in a century so filled with tensions and contradictions in matters of religion, the body, gender, and identity? True, there are many women in the text whose knowledge is far from virtuous, or whose ignorance reflects badly on the female sex. But the insistence on this ambiguity, the openness of the dialogue, and the text's inclusivity make female knowledge explicitly complex, nuanced, and dynamic. By extension, the Heptaméron suggests that language, text, and the telling of stories offer a way for women to explore, question, and wield what they know. The authority of this female network of storytelling-based knowledge is deeply embedded in the Heptaméron: if Marguerite de Navarre holds the pen, Oisille and Parlamente speak the words that set the game of knowledge into action.

\section{University of Nebraska-Lincoln}

\section{Notes}

1. Marguerite de Navarre, Heptaméron (1559), Renja Salminen, ed. (Geneva: Droz, 1999).

2. Because this article examines the textual use of words relating to knowledge, I will focus on the meaning of the word, rather than on its contestation and/or dissemination in early modern France (which is in and of itself a vast topic). See "Savoir" and "Connaître," Le Grand Robert de la langue française, http://lerobert.com.

3. Emile Telle writes, "même après plusieurs lectures, nous n'arrivons pas à faire une idée d'ensemble de l'ouvrage; c'est le défaut de tous les récueils de contes de l'époque, mais il semble que ce soit surtout le cas pour l'Heptaméron" (L'œuvre de Marguerite d'Angoulême, reine de Navarre, et la querelle des femmes [Geneva: Slatkine Reprints, 1969], 94). Recently, scholars have taken the stance that the diversity and openness in the Heptaméron and in Marguerite's euvre more broadly should be embraced. For a good sampling of such scholarship, see A Companion to Marguerite de Navarre, Mary B. McKinley and Gary Ferguson, eds. (Leiden: Brill, 2013).

4. Gérard Défaux, "Marguerite de Navarre et la guerre des sexes," French Forum, 24:2 (1999): 153.

5. Carol Thysell, The Pleasure of Discernment: Marguerite de Navarre as Theologian (New York: Oxford U P, 2000), 86ff.

6. Nancy Frelick, "Female Infidelity: Ideology, Subversion, and Feminist Practice in Marguerite de Navarre's Heptaméron," Dalhousie French Studies, "Le mariage sous l'Ancien Régime," 56 (2001): 17. 


\section{L'ESPRIT CRÉATEUR}

7. Cathleen M. Bauschatz, “'Voylà, mes dames ....' Inscribed Women Listeners and Readers in the Heptaméron," in Critical Tales: New Studies of the Heptaméron and Early Modern Culture, John D. Lyons and Mary B. McKinley, eds. (Philadelphia: U of Pennsylvania P, 1993), 114.

8. Hope Glidden, "Gender, Essence and the Feminine (Heptaméron 43)," in Critical Tales, 37.

9. See Telle, L'ouvre de Marguerite d'Angoulême, 146.

10. Most scholars agree that Marguerite de Navarre's voice is best represented by a combination of Oisille and Parlamente. For a summary of the scholarship on this subject, see P. A. Chilton's introduction to the English translation of the Heptameron (London: Penguin, 1984). For a discussion of the problems associated with this kind of characterization (which has fallen out of favor since the rise of the New Criticism), see Betty J. Davis, The Storytellers in Marguerite de Navarre's Heptaméron (Lexington, KY: French Forum, 1978).

11. See Thysell, The Pleasure of Discernment, 57-60.

12. Gisèle Mathieu-Castellani, La conversation conteuse: Les Nouvelles de Marguerite de Navarre (Paris: PUF, 1992), 204.

13. See Emile Telle, L'œuvre de Marguerite d'Angoulême, chap. 4.

14. It also underscores the equal education that Marguerite shared with her brother; many have hinted that Marguerite's was the greater mind. See Thysell, The Pleasure of Discernment, 6-7.

15. Both novellas have been thoughtfully commented upon by scholars. See Mary McKinley's rich analysis of religious confession in novellas 22, 41, and 72 in "Telling Secrets: Sacramental Confession and Narrative Authority in the Heptameron," in Critical Tales, 146-71. McKinley emphasizes the female narrative authority placed strategically into confessional spaces. The anticlericalism of the Heptaméron is investigated carefully in Gary Ferguson's article, "Mal de vivre, mal croire: L'anticléricalisme de 1'Heptaméron de Marguerite de Navarre," Seizième Siècle, 6 (2010): 151-63. Ferguson considers the significance and nature of the way in which the Heptaméron depicts the corruption of the clergy.

16. Recent scholarship has focused on some of the problems associated with reading the Lady of Pamplona as straightforwardly virtuous. For example, Bruno Méniel points out that the dialogism of the text, which purports to show readers a wise and a foolish woman, actually complicates its own message by subtly undermining the wise lady's decision to dissimulate. See "La vertu et l'orgueil: Étude littéraire de la Nouvelle 26," in Lire l'Heptaméron de Marguerite de Navarre, Dominique Bertrand, ed. (Clermont-Ferrand: Presses Universitaires Blaise Pascal, 2005), 123-36. Judy Kem contextualizes the lady's demise in the context of early modern lovesickness. See "Fatal Lovesickness in Marguerite de Navarre's Heptaméron," The Sixteenth-Century Journal, 41:2 (2010): 355-70. See also Mathieu-Castellani, who takes care to point out that by confessing at the end of her life, the "sage" lady is actually the "folle" (86-89).

17. Paula Sommers, "Vision and Voyeurism in the Heptaméron," Modern Language Studies, 22:1 (1992): 88.

18. Paula Sommers, "Writing the Body: Androgynous Strategies in the Heptameron," in Critical Tales, 235. 